\title{
Quality of life in Arab women with breast cancer: a review of the literature
}

\author{
Bouchra Haddou Rahou ${ }^{1 *}$, Karima El Rhazi ${ }^{2}$, Fatima Ouasmani ${ }^{1}$, Chakib Nejjari ${ }^{2}$, Rachid Bekkali ${ }^{3}$, Ali Montazeri ${ }^{4}$ \\ and Abdelhalem Mesfioui ${ }^{1}$
}

\begin{abstract}
Background: Quality of life has become an important concept in cancer care. Among the quality of lifestudies in cancer patients, breast cancer has received most attention. This review reports on quality of life in Arab patients with breast cancer.

Methods: The search was conducted using inclusion and exclusion criteria and in accordance with Preferred Reporting Items for Systematic Reviews and Meta-Analyses (PRISMA). The databases consulted were PubMed, Sciences Direct, Index Medicus for Wordl Health Organization Eastern Mediterranean, African Journals Online and African Index Medicus.

Results: Thirteen articles from eight countries met the inclusion criteria. The EORTC quality of life questionnaires (QLQ-C30 and QLQ-BR23) were the most used instrument (7 out of 13). The results showed that good scores of global health were recorded at Arab women living in United Arab Emirates (mean score $=74.6$ ) compared to other countries. The results indicated that there was a difference in quality of life scores and its associated factors among Arab women with breast cancer.
\end{abstract}

Conclusion: This paper is the first that reviewed published research on quality of life among Arab women with breast cancer. We found that insufficient results-related information is available.

Keywords: Quality of life, Breast cancer, Arab women

\section{Background}

Quality of life (QOL) has become an important outcome measure in the treatment of cancer patients during the last decade. It is a multidimensional construct encompassing perceptions of both positive and negative aspects of dimensions such as physical, emotional, social and cognitive functions, as well as the negative aspects of somatic discomfort and other symptoms produced by a disease or its treatment [1]. Clinical trials have shown that changes in QOL are associated with changes in clinical variables including survival [2].

It has been shown that assessing QOL in cancer patients could contribute to improve treatment and could be an important prognostic factor [3-6].

\footnotetext{
* Correspondence: hrahoubouchra@yahoo.fr

${ }^{1}$ Laboratory of Genetic, Neuroendocrinology and Biotechnology, University

Ibn Tofail, Faculty of Sciences, Kenitra, Morocco

Full list of author information is available at the end of the article
}

Among the QOL studies in cancer patients, breast cancer has received most attention. This is partly due to the increasing number of patients. Statistics show that breast cancer is by far the most frequent cancer among women in the world, with an estimated 1,67 million new cases diagnosed in 2012 [7]. On the other hand, through early detection programs and more effective treatments, more women with breast cancer are surviving longer [8].

However, the physical, functional, psychological and social difficulties of the women treated for cancer can compromise their QOL. The QOL studies in breast cancer patients reported that anxiety, depression, pain, fatigue, and arm morbidity were the most reported symptoms [9].

Patients receiving chemotherapy might experience several side-effects and symptoms that negatively affect their QOL [9] and patients who underwent mastectomy indicated lower body image and sexual functioning than those who did not [9]. 
Many psychosocial and medical factors, like age, patient education, spousal support and employment status, financial stability, disease stage, have been reported in the literature to predict the QOL of patients $[1,10]$.

The Arab world has a total of 22 countries spread across Northern Africa and Western Asia, including the Middle East. Data from Arab countries on breast cancer vary according to region and country. In Arab countries, the breast cancer represents $14 \%$ to $42 \%$ of all female cancers [11]. Age-adjusted standardized incidence rates (ASR) were reported to vary from 9.5 to 50 cases per 100,000 women per year [11]. $50 \%$ of cases are younger than 50 years compared to $25 \%$ in developed countries [11]. Cancer remains a taboo in most Arab countries [11]. The majority of people still refer to it as "other disease" and remain afraid of mentioning it by name [11]. Arab womenshare a set of different cultural, norms and beliefs and studies have shown that patient-based outcomes could be affected by cultural experiences and ethnic backgrounds [12, 13].

Analysis of a large international database of the European Organization for Research and Treatment in Cancer Quality of Life Questionnaire (EORTCQLQC30) indicated that,compared with patients from the United Kingdom; physical and social functioning were less important in predicting the global QOL of patients from Islamic countries, while cognitive functioning was more influential for South Asia and Latin America [14].

Recently, healthcare providers in Arab countries have started looking at the QOL of women diagnosed and living with breast cancer and the QOL is receiving more and more attention from researchers. The aim of the present review is to collect and examine publication that have appeared in English and French biomedical journals. The findings will constitute an evidence base for the cancer control programs in Arab countries and may reveal findings that will ultimately require a specific approaches for assisting Arab patients according to the specificities of their culture and religion.

\section{Methods}

\section{Search strategy}

The search was conducted to identify studies reporting the QOL in Arab women with breast cancer in accordance with Preferred Reporting Items for Systematic Reviews and Meta-Analyses statement criteria (PRISMA) [15].

A systematic literature search was conducted using PubMed, Sciences direct,Index Medicus for World Health Organization (WHO) Eastern Mediterranean, African Journals Online and African Index Medicus (AIM). The reference lists of all identified publications were checked to retrieve other relevant publications, which were not identified through of the computerised search. until May 2015, without restrictions of language or year of publication.

We use the term quality of life to be synonymous with the expression health-related quality of life.

The search strategy included the following keywords or their combinations in titles of publications:quality of life, health related quality of life, breast cancer, breast carcinoma, North Africa, Middle East, Arabic countries, Morocco, Algeria, Tunisia, Libya, Mauritania, Oman, Saudi Arabia, Bahrain, Comoros, Djibouti, Egypt, United Arab Emirates, Iraq, Jordan, Kuwait, Lebanon, Palestine, Qatar, Somalia, Sudan, Syria, Yemen.

\section{Inclusion and exclusion criteria}

Studies were included if they described aspects of the quality of life or health quality of life in Arab women with breast cancer, and presented the results on the quality of life evencross- cultural adaptation studies.

We excluded studies that did not pertain Arab women or reported on all types of cancers and did not specify the breast cancer. Furthermore, we excluded studies and information published only as abstracts.

\section{Type of studies}

Were included both qualitative and quantitative studies in this review. For the quantitative studies, both observational and interventional were included.

\section{Analyzed outcomes}

The analyzed outcomes were global QOL score, QOL domains, factors associated with QOL, perceptions and attitudes.

\section{Results}

Our findings indicate that studies on QOL in Arab women with breast cancer are very scarce. Indeed, among the 22 Arab countries, only 09 have conducted studies in this field (Fig. 1).

Figure 2 shows the flowchart of the systematic review process followed. The initial search identified a total of 590papers; among them 570 manuscriptswere excluded due to duplication. Twenty potential articles were identified based on the relevance of the abstracts. Followinga thorough review of the full text,thirteen articles were eligible for inclusion.

\section{Characteristics of included studies}

Thirteen studies met the inclusion criteria. All were published between 1997 and 2014. The first study was conducted in 1997 while the second until 2008. The other eleven studies all published in the last six years. The quality assessment of selected studies are shown in Table 1. 


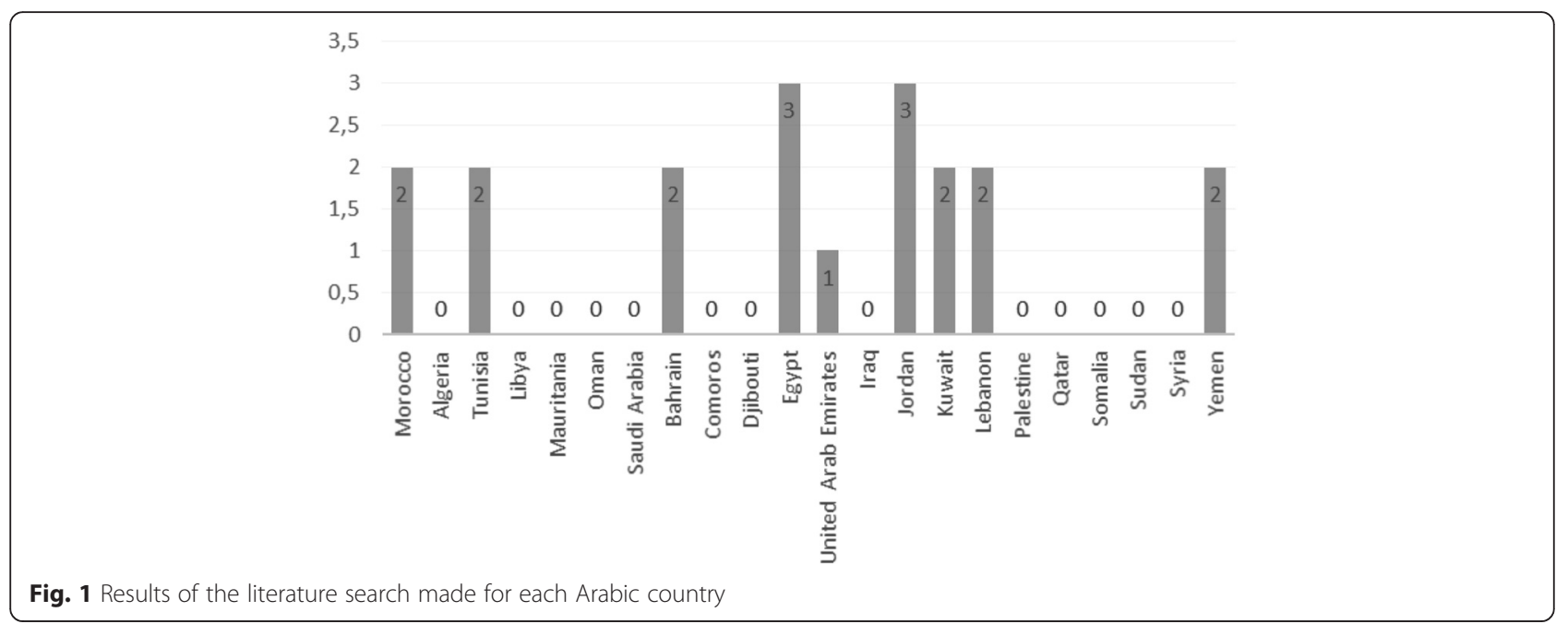

A total of 4132 Arab women with breast cancer were studied in these investigations. Characteristics of the studies are shown in Table 2.

\section{Objectives and study design}

In the Thirteen studies, only one study was qualitative [16] and the remaining twelve were quantitative studies [17-28]. Among the quantitative studies, one was an interventional study [21] and eleven were crosssectional studies [17-19], [22-28].
Two of the studies reported validation or cultural adaptation of QOL questionnaires [18, 27]. Ten articles focused on the impact of breast cancer and its treatment on QOL of women with breast cancer and analyzed the influence of sociodemographic and clinical data [17], [19-26], [28]. The interventional study conducted in Egypt aimed to improve the QOL of affected patients and their families. The intervention was conducted through communication by phone calls, health education messages, restorative (rehabilitative) therapy for needed cases, social and financial

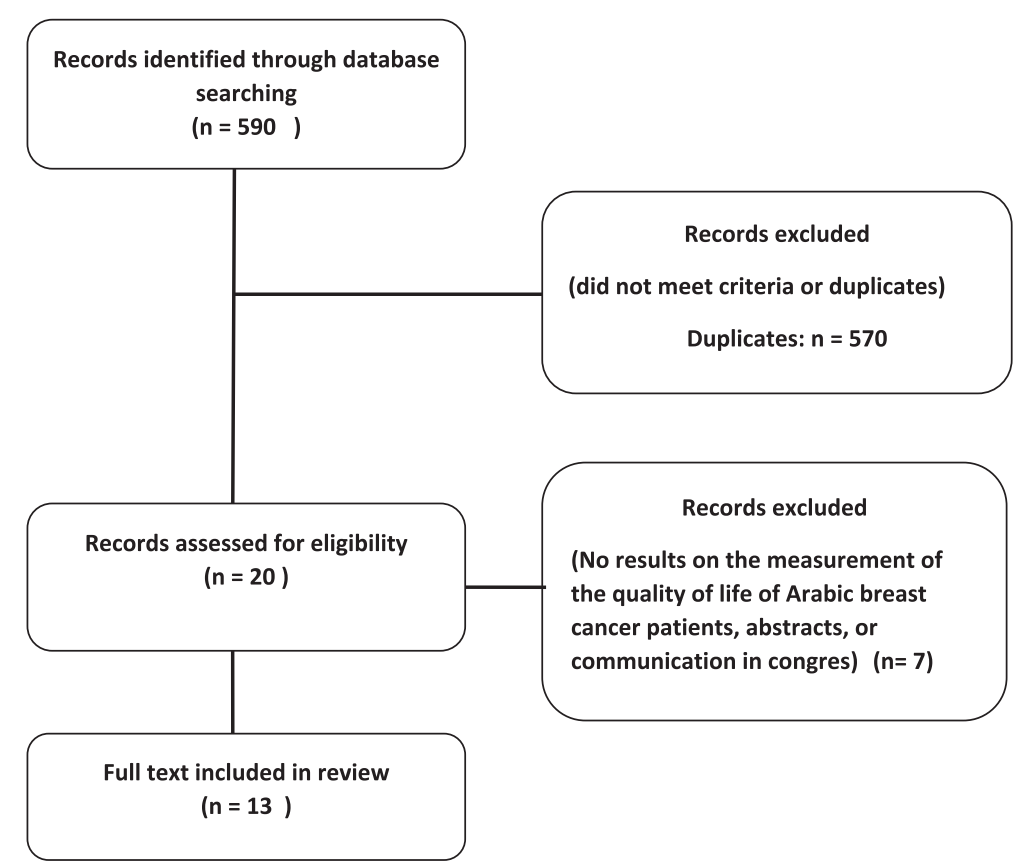

Fig. 2 Flow chart of process of systematic literature search in accordance with PRISMA 
Table 1 Quality assessment of included studies on "Quality of life of Arabic women with breast cancer"

\begin{tabular}{|c|c|c|c|c|c|c|c|c|c|c|}
\hline Author/Reference & $\begin{array}{l}\text { Relevant } \\
\text { to this SR }\end{array}$ & $\begin{array}{l}\text { Aims } \\
\text { clearly } \\
\text { stated }\end{array}$ & $\begin{array}{l}\text { Appropriate } \\
\text { study method }\end{array}$ & $\begin{array}{l}\text { Sample } \\
\text { representative of } \\
\text { target population }\end{array}$ & $\begin{array}{l}\text { Confounding } \\
\text { and bias } \\
\text { considered }\end{array}$ & $\begin{array}{l}\text { Good } \\
\text { response } \\
\text { rate? }\end{array}$ & $\begin{array}{l}\text { Were questions } \\
\text { piloted/validated? }\end{array}$ & $\begin{array}{l}\text { Tables/figures } \\
\text { understandable }\end{array}$ & $\begin{array}{l}\text { Can results be } \\
\text { applied to local } \\
\text { situation? }\end{array}$ & $\begin{array}{l}\text { Accepted as } \\
\text { Type IV } \\
\text { evidence? }\end{array}$ \\
\hline El Sharkawi et al. [17] & Yes & Yes & Yes & No & Yes & Yes & Yes & Yes & Yes & Yes \\
\hline Awad et al. [18] & Yes & Yes & Yes & No & Yes & Yes & Yes & Yes & $\begin{array}{l}\text { Yes (just for breast } \\
\text { cancer patients) }\end{array}$ & Yes \\
\hline Alawadi and Ohaeri [19] & Yes & Yes & Yes & No & Yes & Yes & Yes & Yes & Yes & Yes \\
\hline Masmoudi et al. [20] & Yes & Yes & Yes & No & Yes & Yes & Yes & Yes & Yes & Yes \\
\hline Mostafa et al. [21] & Yes & Yes & Yes & No & ND & Yes & Yes & Yes & Yes & No (type II) \\
\hline Al-Naggar et al. [22] & Yes & Yes & Yes & No & Yes & Yes & Yes & Yes & Yes & Yes \\
\hline Huijer and Abboud [23] & Yes & Yes & Yes & No & Yes & Yes & Yes & Yes & Yes & Yes \\
\hline Denewer et al. [24] & Yes & Yes & Yes & No & ND & Yes & Yes & Yes & Yes & Yes \\
\hline Ba-Khubaira and Al-Kahiry [25] & Yes & Yes & Yes & No & Yes & Yes & Yes & Yes & Yes & Yes \\
\hline Jassim and Whitford [26] & Yes & Yes & Yes & Yes & Yes & Yes & Yes & Yes & Yes & Yes \\
\hline Jassim and Whitford [16] & Yes & Yes & Yes & No & Yes & Yes & $\begin{array}{l}\text { ND (qualitative } \\
\text { study) }\end{array}$ & Yes & Yes & Yes \\
\hline El Fakir et al. [27] & Yes & Yes & Yes & No & Yes & Yes & Yes & Yes & $\begin{array}{l}\text { Yes (not for other } \\
\text { regional languages) }\end{array}$ & Yes \\
\hline Abu-Helalah et al. [28] & Yes & No & Yes & No & Yes & Yes & Yes & Yes & Yes & Yes \\
\hline
\end{tabular}


Table 2 Characteristics of included studies

\begin{tabular}{|c|c|c|c|c|c|c|c|}
\hline Author/Year/Reference & Country and setting & $\begin{array}{l}\text { Study design and } \\
\text { Population }\end{array}$ & Main focus & QOL Assessment & Outcome & Comparison & $\begin{array}{l}\text { Main finding and } \\
\text { effects }\end{array}$ \\
\hline El Sharkawi et al. [17] & $\begin{array}{l}\text { Egypt } \\
\text { Surgery and clinical and } \\
\text { nulear Medicine } \\
\text { departments, Alexandria } \\
\text { Men University Hospital }\end{array}$ & $\begin{array}{l}\text { Cross sectional study } \\
272 \text { women with early } \\
\text { Breast cancer who are } \\
\text { under treatment }\end{array}$ & $\begin{array}{l}\text { Determine the } \\
\text { effects of the } \\
\text { treatment on the } \\
\text { QOL of Egyptian } \\
\text { women with early } \\
\text { Breast Cancer }\end{array}$ & $\begin{array}{l}\text { Linear analogue } \\
\text { self-assessment } \\
\text { (LASA) scales }\end{array}$ & $\begin{array}{l}\text { the four domains of QOL } \\
\text { of women having } \\
\text { adjuvant therapy were } \\
\text { significantly altered } \\
\text { compared to those who } \\
\text { underwent mastectomy } \\
\text { alone triple modality } \\
\text { adversely affected global } \\
\text { QL the most compared } \\
\text { to radiotherapy or } \\
\text { chemotherapy } \\
\text { radiotherapy had } \\
\text { significantly less effect on } \\
\text { QL compared to } \\
\text { chemotherapy triple } \\
\text { modality predicted the } \\
\text { worst QOL }\end{array}$ & $\begin{array}{l}\text { Patients were divided } \\
\text { into four groups: } \\
\text { 1. mastectomy alone, } \\
\text { 2. surgery plus } \\
\text { radiotherapy, } \\
\text { 3. surgery plus } \\
\text { chemotherapy } \\
\text { 4. triple modality }\end{array}$ & $\begin{array}{l}\text { Quality of life } \\
\text { measures should } \\
\text { be incorporated } \\
\text { in the evaluation } \\
\text { of treatment } \\
\text { Patients should } \\
\text { receive health } \\
\text { education on the } \\
\text { effects of each } \\
\text { therapy }\end{array}$ \\
\hline Awad et al. [18] & $\begin{array}{l}\text { United Arab Emirates } \\
\text { The Breast Cancer Clinic } \\
\text { at Tawam Hospital, } \\
\text { Al Ain }\end{array}$ & $\begin{array}{l}\text { Cross sectional study } \\
87 \text { women with breast } \\
\text { cancer and who are of } \\
\text { Arabic origin } \\
3 \text { months after surgical } \\
\text { treatment }\end{array}$ & $\begin{array}{l}\text { Assess the } \\
\text { psychometric } \\
\text { properties of the } \\
\text { Arabic version of } \\
\text { the EORTC QLQ- } \\
\text { C30 and } \\
\text { QLQ-BR23 in Arab } \\
\text { breast cancer } \\
\text { patients }\end{array}$ & $\begin{array}{l}\text { The Arabic version } \\
\text { of EORTC QLQ- } \\
\text { C } 30 \text { and QLQ- } \\
\text { BR23 }\end{array}$ & $\begin{array}{l}\text { Participants had a mean } \\
\text { score for global QOL of } \\
74.6 \\
\text { The QLQ-C30 discriminated } \\
\text { between mastectomy and } \\
\text { lumpectomy patients on } \\
\text { the emotional and cogni- } \\
\text { tive function scales and } \\
\text { QLQ-BR23 discriminated as } \\
\text { well on the function scales } \\
\text { and for systemic side } \\
\text { effects. }\end{array}$ & $\begin{array}{l}\text { Group I: } \\
\text { mastectomy patients } \\
\text { Group II: } \\
\text { lumpectomy patients }\end{array}$ & $\begin{array}{l}\text { Patients' } \\
\text { perceptions } \\
\text { extend beyond } \\
\text { the negative } \\
\text { physical and } \\
\text { functional impact } \\
\text { of cancer to the } \\
\text { individuals' } \\
\text { perceptions of } \\
\text { their general well- } \\
\text { being. }\end{array}$ \\
\hline Alawadi and Ohaeri [19] & $\begin{array}{l}\text { Kuwait } \\
\text { The medical oncology } \\
\text { department of the Kuwait } \\
\text { Cancer Control Center }\end{array}$ & $\begin{array}{l}\text { Cross-sectional a } \\
\text { comparative study using } \\
\text { the EORTC Quality of Life } \\
\text { Questionnaire } \\
348 \text { women with breast } \\
\text { cancer receiving } \\
\text { chemotherapy }\end{array}$ & $\begin{array}{l}\text { Highlight the } \\
\text { HRQOL scale } \\
\text { scores for Kuwaiti } \\
\text { women in stable } \\
\text { clinical condition } \\
\text { with breast cancer, } \\
\text { in comparison } \\
\text { with the } \\
\text { international data. } \\
\text { Assess the socio- } \\
\text { demographic and } \\
\text { clinical variables } \\
\text { that predict the } \\
\text { five functional } \\
\text { scales and global } \\
\text { QOL (GQOL) scale } \\
\text { of the QLQ - C } 30\end{array}$ & $\begin{array}{l}\text { The Arabic version } \\
\text { of EORTC QLQ- } \\
\text { C30 and QLQ- } \\
\text { BR23 }\end{array}$ & $\begin{array}{l}\text { The mean score of global } \\
\text { QOL scale (GQOL) was } \\
45.3 \\
\text { The patients had poor to } \\
\text { average functioning and } \\
\text { intense symptom } \\
\text { experience. } \\
\text { Younger women had } \\
\text { poorer HRQOL scores } \\
\text { The significant } \\
\text { associations of disease } \\
\text { stage with role } \\
\text { functioning, diarrhea and } \\
\text { future perspective } \\
\text { In regression analysis, } \\
\text { social functioning } \\
\text { accounted for the highest } \\
\text { proportion of variance for } \\
\text { GQOL. }\end{array}$ & - & $\begin{array}{l}\text { The biological } \\
\text { and treatment } \\
\text { side effect factors } \\
\text { seemed to be } \\
\text { more important } \\
\text { than family and } \\
\text { institutional } \\
\text { supports } \\
\text { A longitudinal } \\
\text { study is needed } \\
\text { to confirm this } \\
\text { trend. }\end{array}$ \\
\hline
\end{tabular}


Table 2 Characteristics of included studies (Continued)

\begin{tabular}{|c|c|c|c|c|c|c|c|}
\hline Masmoudi et al. [20] & $\begin{array}{l}\text { Tunisia } \\
\text { Department of Medical } \\
\text { Oncology in Sfax } \\
\text { University } \\
\text { Hospital }\end{array}$ & $\begin{array}{l}\text { Descriptive study } \\
23 \text { women with early } \\
\text { breast cancer receiving } \\
\text { adjuvant chemotherapy }\end{array}$ & $\begin{array}{l}\text { Assess the } \\
\text { feasibility of QOL } \\
\text { assessment in a } \\
\text { cohort of Tunisian } \\
\text { cancer patients }\end{array}$ & $\begin{array}{l}\text { The Arabic version } \\
\text { of EORTC QLQ- } \\
\text { C } 30\end{array}$ & $\begin{array}{l}\text { Participants had a mean } \\
\text { score for global QOL of } \\
72.5 \text { pre chemo } \\
\text { And } 68.5 \text { during chemo. } \\
\text { A significant deterioration } \\
\text { in physical, cognitive, and } \\
\text { social functioning, } \\
\text { between the pre- } \\
\text { treatment and on- } \\
\text { treatment assessments }\end{array}$ & $\begin{array}{l}\text { Group I: } \\
\text { pre-treatment } \\
\text { Group II: } \\
\text { on-treatment }\end{array}$ & $\begin{array}{l}\text { improvement of } \\
\text { cancer care } \\
\text { infrastructure and } \\
\text { public education } \\
\text { is still needed } \\
\text { before reliable } \\
\text { QOL studies can } \\
\text { be performed }\end{array}$ \\
\hline Mostafa et al. [21] & $\begin{array}{l}\text { Egypt } \\
\text { El- Minia oncology center }\end{array}$ & $\begin{array}{l}\text { Interventional hospital } \\
\text { based study, } 180 \text { female } \\
\text { breast cancer patients } \\
\text { recei-ving treatment }\end{array}$ & $\begin{array}{l}\text { Assess QOL, its } \\
\text { relation to } \\
\text { different variables } \\
\text { related to cancer } \\
\text { Trial to improve } \\
\text { the QOL of } \\
\text { patients and their } \\
\text { families through } \\
\text { communication, } \\
\text { counseling, } \\
\text { restorative } \\
\text { (rehabilitative) } \\
\text { therapy, social and } \\
\text { medical support. }\end{array}$ & $\begin{array}{l}\text { The Arabic version } \\
\text { of EORTC QLQ- } \\
\text { C } 30 \text { and QLQ- } \\
\text { BR23 }\end{array}$ & $\begin{array}{l}38.3 \% \text { of studied females } \\
\text { had poor global health } \\
\text { status/QOL } \\
52.8 \% \text { had good global } \\
\text { health status/QOL } \\
\text { There is a significant } \\
\text { change in physical, role, } \\
\text { emotional, cognitive and } \\
\text { social functioning in pre- } \\
\text { and post-intervention } \\
\text { assessment. }\end{array}$ & $\begin{array}{l}180 \text { female breast cancer } \\
\text { patients in pre-intervention } \\
75 \text { patients (with global } \\
\text { health status/QOL score } \\
\text { value of } \leq 50 \text { ) in post } \\
\text { intervention phase }\end{array}$ & $\begin{array}{l}\text { Need to provide } \\
\text { comprehensive } \\
\text { care for breast } \\
\text { cancer survivors }\end{array}$ \\
\hline Al-Naggar et al. [22] & $\begin{array}{l}\text { Yemen } \\
\text { The outpatient of } \\
\text { National Oncology Centre } \\
\text { (NOC), Sana'a }\end{array}$ & $\begin{array}{l}\text { Cross-sectional study } \\
106 \text { female breast cancer } \\
\text { patients underwent } \\
\text { treatment. }\end{array}$ & $\begin{array}{l}\text { Determine the } \\
\text { QOL among breast } \\
\text { cancer patients in } \\
\text { Yemen based on } \\
\text { socio-demographic } \\
\text { and clinical } \\
\text { characteristics }\end{array}$ & $\begin{array}{l}\text { Functional } \\
\text { Assessment of } \\
\text { Cancer Treatment- } \\
\text { Breast (FACT-B) } \\
\text { questionnaire }\end{array}$ & $\begin{array}{l}\text { Years after diagnosis, } \\
\text { family monthly income } \\
\text { and radiotherapy were } \\
\text { significantly associated } \\
\text { with total QOL of the } \\
\text { breast cancer patients }\end{array}$ & - & $\begin{array}{l}\text { Age, occupation, } \\
\text { family history of } \\
\text { breast cancer, size } \\
\text { of tumor, } \\
\text { chemotherapy } \\
\text { and tamoxifen } \\
\text { were not } \\
\text { significantly } \\
\text { influence QOL }\end{array}$ \\
\hline Huijer and Abboud [23] & $\begin{array}{l}\text { Lebanon } \\
\text { American University of } \\
\text { Beirut-Medical Center } \\
\text { (AUB-MC) }\end{array}$ & $\begin{array}{l}\text { Cross-sectional descriptive } \\
\text { survey } \\
200 \text { Lebanese adult } \\
\text { patients with cancer } \\
\text { including } 89 \text { women with } \\
\text { breast cancer who are } \\
\text { diagnosed for more than } \\
\text { one month }\end{array}$ & $\begin{array}{l}\text { Evaluate the QOL, } \\
\text { symptom } \\
\text { prevalence and } \\
\text { management, } \\
\text { functional ability, } \\
\text { and quality of care } \\
\text { provided to } \\
\text { Lebanese women } \\
\text { with BC }\end{array}$ & $\begin{array}{l}\text { The Arabic version } \\
\text { EORTC-QLQ-C30 }\end{array}$ & $\begin{array}{l}\text { Mean score for global } \\
\text { QOL: } 59.64 \\
\text { High scores were } \\
\text { reported on functional } \\
\text { ability, medical care, } \\
\text { spirituality, and } \\
\text { relationships. } \\
\text { Factors significantly } \\
\text { associated with QOL: } \\
\text { Payments per month for } \\
\text { medical expenses, } \\
\text { presence of metastasis, } \\
\text { time since diagnosis, } \\
\text { symptoms, and type of } \\
\text { treatment received. }\end{array}$ & - & $\begin{array}{l}\text { The impact of } \\
\text { clinical } \\
\text { characteristics on } \\
\text { QOL is far more } \\
\text { significant than } \\
\text { demographic } \\
\text { characteristics }\end{array}$ \\
\hline
\end{tabular}

ge, occupation, of tumor,

chemotherapy were not fluence QOL

The impact of $\mathrm{QOL}$ is far more significant than demographic treatment received. 
Table 2 Characteristics of included studies (Continued)

\begin{tabular}{|c|c|c|c|c|c|c|c|}
\hline Denewer et al. [24] & $\begin{array}{l}\text { Egypt the Oncology } \\
\text { Center-Mansoura } \\
\text { University }\end{array}$ & $\begin{array}{l}\text { Prospective study } \\
200 \text { Egyptian women } \\
\text { within } 2 \text { months-2 years } \\
\text { from their primary } \\
\text { surgery }\end{array}$ & $\begin{array}{l}\text { Evaluate QOL, } \\
\text { body image, and } \\
\text { patient } \\
\text { satisfaction } \\
\text { comparing } \\
\text { between } \\
\text { traditional } \\
\text { mastectomy alone } \\
\text { and sparing } \\
\text { mastectomy with } \\
\text { immediate } \\
\text { autologous breast } \\
\text { reconstruction }\end{array}$ & $\begin{array}{l}\text { Breast impact of } \\
\text { treatment scale } \\
\text { (BITS) } \\
\text { Body satisfaction } \\
\text { scale (BSS) }\end{array}$ & $\begin{array}{l}\text { Patient with breast } \\
\text { reconstruction had a high } \\
\text { mean score of BSS: } 14.44 \\
\text { out of total degrees of } 20 \\
\text { No difference was found } \\
\text { between the two groups } \\
\text { as regard the BITS score }\end{array}$ & $\begin{array}{l}\text { Group I: } \\
\text { patients underwent } \\
\text { sparing mastectomy with } \\
\text { immediate autologous } \\
\text { breast reconstruction } \\
\text { Group II: } \\
100 \text { Patients underwent } \\
\text { traditional mastectomy }\end{array}$ & $\begin{array}{l}\text { Egyptian women } \\
\text { with breast } \\
\text { cancer show } \\
\text { better QOL and } \\
\text { body image } \\
\text { satisfaction } \\
\text { outcomes } \\
\text { following } \\
\text { immediate breast } \\
\text { reconstruction. }\end{array}$ \\
\hline $\begin{array}{l}\text { Ba-Khubaira and Al-Kahiry } \\
\text { [25] }\end{array}$ & $\begin{array}{l}\text { Yemen } \\
\text { Central Public Health } \\
\text { Laboratories - Aden } \\
\text { branch }\end{array}$ & $\begin{array}{l}\text { Cross-sectional study } \\
58 \text { Yemeni patients with } \\
\text { early stage breast cancer. } \\
\text { During follow-up for the } \\
\text { last } 2 \text { years after they fin- } \\
\text { ished treatment. }\end{array}$ & $\begin{array}{l}\text { Determine the } \\
\text { QOL of Yemeni } \\
\text { patients in Aden } \\
\text { after treatment of } \\
\text { early stage breast } \\
\text { cancer below } \\
50 \text { years compared } \\
\text { to } 50 \text { years and } \\
\text { more of age. }\end{array}$ & $\begin{array}{l}\text { FACT-B } \\
\text { Questionnaire }\end{array}$ & $\begin{array}{l}\text { The overall QOL reported } \\
\text { in this study among breast } \\
\text { cancer Yemeni patients in } \\
\text { Aden was } 77.6 \text { and the } \\
\text { breast cancer-specific sub- } \\
\text { scale (BCS) was } 21.2 \text {. } \\
\text { Yemeni patients with } \\
\text { early breast cancer are } \\
\text { having lower QOL after } \\
\text { treatment; this QOL was } \\
\text { deteriorated among } \\
\text { younger patients when } \\
\text { compared to older } \\
\text { patients. }\end{array}$ & $\begin{array}{l}\text { Group I: early stage breast } \\
\text { cancer below } 50 \text { years } \\
\text { Group II: } 50 \text { years and } \\
\text { more of age. }\end{array}$ & $\begin{array}{l}\text {-Evaluation of the } \\
\text { post-treatment } \\
\text { QOL of cancer pa- } \\
\text { tients should be a } \\
\text { part of the evalu- } \\
\text { ation criteria of } \\
\text { cancer therapy in } \\
\text { Aden. }\end{array}$ \\
\hline Jassim and Whitford [26] & $\begin{array}{l}\text { Bahrain } \\
\text { The main governmental } \\
\text { Hospital, Salmaniya } \\
\text { Medical Complex }\end{array}$ & $\begin{array}{l}\text { Descriptive cross sectional } \\
\text { study } 239 \text { Bahraini breast } \\
\text { cancer survivors }\end{array}$ & $\begin{array}{l}\text { Describe the QOL } \\
\text { of Bahraini women } \\
\text { with breast cancer } \\
\text { and its association } \\
\text { with their } \\
\text { sociodemographic } \\
\text { and clinical data. }\end{array}$ & $\begin{array}{l}\text { The Arabic version } \\
\text { of EORTC-QLQ- } \\
\text { C } 30\end{array}$ & $\begin{array}{l}\text { Participants had a mean } \\
\text { score for global QOL of } \\
63.9 \\
\text { Average to good QOL } \\
\text { functioning and low to } \\
\text { average symptoms } \\
\text { experience } \\
\text { Factors associated to } \\
\text { lower QOL: marital status, } \\
\text { menopausal status, } \\
\text { metastases, monthly } \\
\text { income and type of } \\
\text { surgery. }\end{array}$ & - & $\begin{array}{l}\text { Bahraini BC } \\
\text { survivors reported } \\
\text { favorable overall } \\
\text { global quality of } \\
\text { life. } \\
\text { Special care } \\
\text { should be given } \\
\text { to women with } \\
\text { cancer related } \\
\text { symptoms and } \\
\text { metastatic lesions }\end{array}$ \\
\hline Jassim and Whitford [16] & $\begin{array}{l}\text { Bahrain } \\
\text { Oncology Center in } \\
\text { Salmaniya Medical } \\
\text { Complex }\end{array}$ & $\begin{array}{l}\text { Qualitative study } \\
12 \text { Bahraini women } \\
\text { diagnosed with breast } \\
\text { cancer. Who were } \\
\text { deemed to have coped } \\
\text { to differing degrees both } \\
\text { during and following } \\
\text { their initial diagnosis. }\end{array}$ & $\begin{array}{l}\text { Explore the } \\
\text { Experiences, } \\
\text { beliefs, perceptions } \\
\text { and attitudes of } \\
\text { Bahraini women } \\
\text { with breast cancer } \\
\text { towards their } \\
\text { quality of life. }\end{array}$ & & $\begin{array}{l}\text { Global QOL was } \\
\text { expressed in terms of } \\
\text { being able to perform } \\
\text { every day chores and the } \\
\text { ability to function in one's } \\
\text { daily role as a woman, } \\
\text { wife, daughter and } \\
\text { employee } \\
\text { Hair loss was a major side } \\
\text { effect of treatment the }\end{array}$ & - & $\begin{array}{l}\text { The finding aid } \\
\text { healthcare } \\
\text { professionals in } \\
\text { planning } \\
\text { appropriate } \\
\text { interventions that } \\
\text { meet the patients' } \\
\text { needs }\end{array}$ \\
\hline
\end{tabular}


Table 2 Characteristics of included studies (Continued)

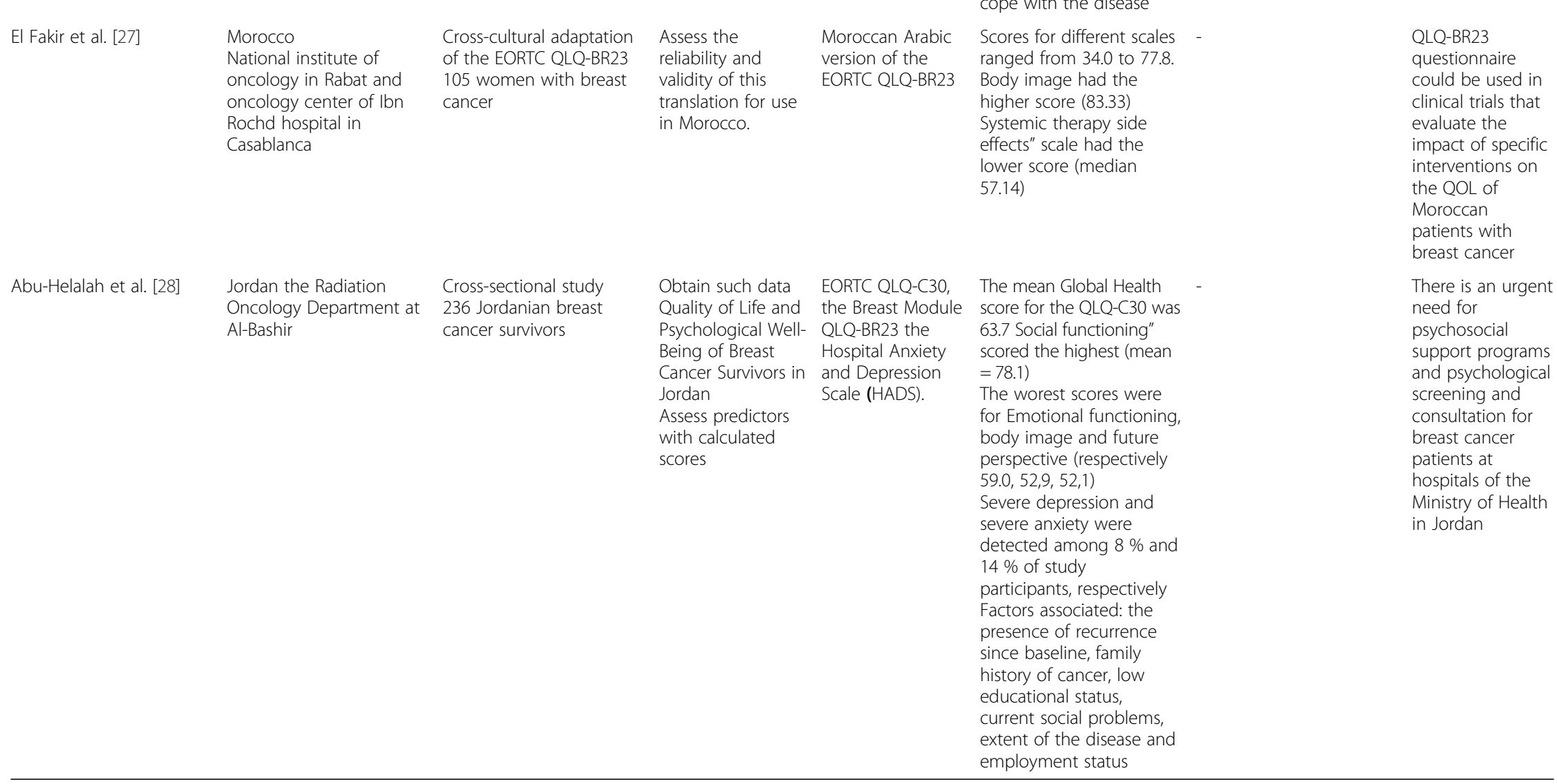

important role played by

the family and husband

in treatment decisions

the use of traditional

clothing (hijab and abaya)

to hide hair and body

changes

the importance of

spirituality and religion to

questionnaire

could be used in

ical trials that

mpact of specific

terventions on

Moroccan

patients with

There is an urgent

support programs

and psychological

reast cancer

hospitals of the

Ministry of Health

Severe depression and

sere anxiety were

of among 
support [21]. The qualitative study conducted in Bahrain explored the experiences, beliefs, perceptions and attitudes of women with breast cancer towards their QOL [16].

\section{Questionnaires}

The EORTC questionnaires were used in seven studies. Three of them used only the QLQ-C30 [20, 23, 26], four used both The EORTC QLQ - C30 and theEORTCbreast cancer- specific quality of life questionnaire (EORTCQLQ-BR23) $[18,19,21,28]$ and one study used only the specific module for breast cancer the QLQBR23 [27]. The studies conducted in Yemen have used the Functional Assessment of Cancer Therapy- Breast (FACT-B) questionnaire to assess the QOL [22, 25]. Other questionnaires were used in two studies conducted in Egypt namely the Breast Impact of Treatment Scale (BITS) [24] and Linear Analogue Self-Assessment Scales (LASA) [17].

\section{Global quality of life}

Concerning studies using the QLQ-C30, good scores of global QOL were recorded for Arab women living in United Arab Emirates (UAE) and also for Tunisian, Bahraini and Jordanian women with mean score of 74.6,68.5, 63.9, 63.7 respectively $[18,20,26,28]$. The score obtained for Lebanese [23] was 59.64 while the Kuwaiti women [19] had lower score (45.30).

The first QOL study conducted among Arab women was in Egypt in 1997 has used a LASA and the results were focused on the impact of the modality of treatment on the QOL [17]. The study conducted by Mostafa et al. shown that $38.3 \%$ of Egyptian patients had poor global QOL and $52.8 \%$ had good global QOL [21]. Another study conducted also in Egypt used the BITS and Body Satisfaction scale (BSS) but has not given any scores of QOL [24]. The study conducted in Yemen used FACT-B and reported 77.6 as overall QOL [25].

\section{Functioning and Symptoms}

According to the EORTC QLQ-C30 and the EORTC BR23 scores, Arab patients with breast cancer have an average to intense symptoms experience. Within the functional scales, the worst scores were for emotional functioning, body image and future perspective [19, 23, 26, 28].

In Kuwait, findings showed that patients were optimistic about their future health. The best domains of QOL were cognitive, social and sexual functioning. Domains with low scores were general wellbeing and physical functioning. Intense level of symptom experience was hair loss [19]. High scores were reported on functional ability, medical care, spirituality, and relationships for Lebanese women with breast cancer and the most common symptoms were nervousness, sadness, lack of energy and pain [23]. Among Bahraini patients, social functioning scored the highest, whereas emotional functioning and sexual functioning scored the lowest. In addition, the most distressing symptom was fatigue, followed by hair loss as the most intense symptom [26]. Similarly, in Jordan the social functioning scored the highest and emotional functioning, body image and future perspective scored the lowest. Hair loss cased the worst symptom [28].

\section{Factors associated with QOL}

Studies conducted among Arab women with breast cancer have identified socio-demographic and clinical factors associated with QOL. Results of studies conducted in UAE, Yemen, Libanon and Bahrain have shown strong relationship between clinical factors and QOL. As a result family history of cancer, menopausal status, presence of metastasis, time since diagnosis, symptoms, disease stage, presence of side effects and type of treatment received were significantly associated with QOL [18, 22, 23, 26].

On the other hand, the studies conducted in Yemen, Lebanon and Jordan have highlighted the association of some sciodemographic factors and the QOL of patients[22, 23, 28]. Most factors identified in these studies were monthly income, payments per month for medical expenses andeducational status.

The study conducted in Tunisia showed a significant deterioration in physical, cognitive and social functioning among patients undergoing treatment [20]. In Egypt, the interventional study conducted by Mostapha et al. revealed a significant change in physical, role, emotional, cognitive and social functioning in pre-and postintervention assessment[21]. A strong relationship was also found among Egyptian patients between QOL and type of treatment, disease stage and presence of secondaries [21].

The results of the two studies conducted in Yemen [22, 25] were different regarding the relationship between age and QOL. The study conducted in 2011 concluded the absence of this relationship [22] while the second conducted in 2012 revealed that Younger women ( $<50$ years) showed significantly lower QOL scores than older women ( $\geq 50$ years) in all of the QOL subscales [25].

\section{Results of the qualitative study}

The qualitative study conducted in Bahrain explored the experiences of women who have survived breast cancer and their perception of QOL after diagnosis. Global QOL was expressed by participants in terms of being able to perform every day chores and the ability to function in their daily role as a woman, wife, daughter and employee. The study revealed the important role played by the family and husband in treatment decisions and 
the importance of spirituality and religion to cope with the disease [16].

\section{Discussion}

The objective of this study was to review published research into QOL among Arab women with breast cancer; analyse the characteristics of these studies and the main results reported. Our review paper focused only on breast cancer and have included both qualitative and quantitative papers.

In Arab countries, breast cancer accounts for $14 \%$ to $42 \%$ of all cancers in women. The physical, functional, psychological and social problems that women live may affect their quality of life. However, the results indicate that research into the QOL of breast cancer patients is poorly developed in Arab countries. After an extensive literature review, we have identified only 13 articles that met inclusion criteria. Despite the general recommendation to include QOL as an outcome in clinical studies involving breast cancer patients [29].

The quantitative studies included in this review focused on the impact of breast cancer and its treatment on QOL and analyzed the influence of socio demographic and clinical data $[17,19-26,28]$. While the qualitative study conducted in Bahrain explored the experiences, beliefs, perceptions and attitudes of women with breast cancer towards their QOL [16].

This review of studies using EORTC C-30 questionnaire shows that the scores of QOL of Arabwomen with breast cancer differ from country to country. Therefore the mean scores of QOL varies from 45.3 to 74.6 on a scale of 100 and good scores were recorded at UAE, Tunisia, Bahrain and Jordan. The lowest mean score was recorded among Kuwaiti Patients (45.3).

Nonetheless, we must be cautious in comparing data from these studies. The literature using the EORTC QLQ-C30 indicates that comparison of data should go beyond the usual presentation of mean scores and significant differences [30-33]. Disparity in QOL scores among Arab women can be related to different interpretation of QOL and selection bias. Indeed the population under the study vary in terms of time since diagnosis, disease stage, treatment received and the questionnaire used might contributed to the observed differences. For instance, studies conducted in Bahrain and Jordan evaluated the QOL of breast cancer survivors, while the researchers in UAE evaluated the QOL of patients under treatment, and studies conducted in Kuwait and Tunisia were carried out among patients under chemotherapy. Moreover, the studies conducted in Yemen and Egypt have used other types of questionnaires and thus the difficulty to compare their results with the other studies remains.
Consistent with other international studies conducted in Australia and Sweden $[34,35]$, the findings of our review showed that breast cancer and its treatment affect the QOL of patients in physical, psychological and social domains. Among functional scales, high scores were reported onsocial functioning in Kuwaiti, Lebanese, Bahraini and Jordanian patients $[19,23,26,28]$. Whereas the emotional functioning scored the lowest in Jordanian and Bahraini $[26,28]$. Arab patients with breast cancer had average to intense symptoms experience and intense level of symptom experience was hair loss [19, 26, 28].

One of the reasons for having pooremotional functioning may be related to the fact that women with breast cancer have to deal not only with the trauma of disfigurement but also with the fear of rejection by their partners and loss of femininity [36]. They also are subjected to too much pressure because of the burden of working in different fields in addition to the commitments of their roles as mothers and housewives.

The social domain had the highest scores among QOL subscales. This may be referred to effective social support system in the Arab communitieswich plays an important role in reducing the pressure and improving health. The experience of patients is usually influenced by the spiritual and religious context characterized by the solidarity and support. Many studies supported these findings, Hebert et al. indicated that positive religious coping methods predict better mental health and life satisfaction in women with breast cancer [37].

In line with other research on QOL of breast cancer [38-41], the findings of studies conducted among Arab women have shown that clinical and socio demographic factors were associated with QOL. The most clinical factors studied was the type of treatment. The triple modality of treatment predicted the worst QOL [17]. the radiotherapy had significantly less effect compared to chemotherapy $[17,22]$. Patients who underwent mastectomy reported lower levels of emotional, cognitive functions, more side effects of treatment and arm symptoms than patients who had undergone lumpectomy [18]. But no difference was found between the patients who underwent mastectomy with reconstruction and those who had mastectomy alone [24].

Similar themes to other studies emerged in terms of impact of socio demographic factors on QOL $[39,40]$. The most identified in our review were monthly income, payments per month for medical expenses and educational status. This is supported by many studies which indicated that increased QOL scores were significantly correlated with increased education and better socioeconomics status [22, 38, 40], [42-44]. In Denmark, Peuckmann and his colleagues [45] reported that poor QOL was significantly associated with short education. The same findings were also reported by Esbensen and others [46] who 
showed that poor economy was associated with low QOL. The family income was significantly influencing the overall QOL as reported by Pandey et al. [47]. The possible justification for this findingsis the ability of the educated women to understand the nature of the disease and to comply with the therapeutic regime more than the uneducated. Moreover, illiterate women with low income are less likely to be screened for breast cancer, would delay seeking care in the presence of symptoms and were diagnosed in later stages of the disease [22].

Although the results of other studies have shown the relationship between age and the QOL of breast cancer patients $[39,48]$. Only the study by Sawsan Ba-Khubaira et al. in Yemen has demonstrated this relationship among Arab patients [25]. The findings for the association of age with QOL are conflicting; some correlated poorer QOL with increasing age $[49,50]$, while others found that younger age patients had more physical wellness and better overall QOL [51]. The inconsistency of these studies may be explained by differences in population background, source of subjects and sample size.

The impact of socio demographic characteristics was far different between Arab countries. This may be explained by economic differences and health policy especially the implementation of early detection and treatment programs of breast cancer.

\section{Implications for practice and policy}

The results highlight the need of a holistic care and the importance of taking into consideration the cultural and religious specificities in the treatment of Arab women with breast cancer. Future research should test intervention to assist Arab women to increase their personal optimism, reduce symptom distress and enhance coping strategies. The findings call for the institution of a psychooncology services to address psycho-social outcomes.

\section{Limitations of this review}

Every effort was made to provide a comprehensive and systematic review of the literature. However, it is possible that some studies may not have been captured in the search and screening process and other did not meet inclusion criteria [52-58] (Additional file 1). Also, the difference of the base populations and the questionnaires used to measure QOL does not allow a comparison of QOL between Arab women. It is worth noting that the majority of studies were cross-sectional and had a small sample size and thus the findings could not be generalized to all Arab women with breast cancer.

\section{Conclusion}

This study investigated for the first time published research on QOL among Arab women with breast cancer even though insufficient information is available on
QOL in Arab women with breast cancer. Certainly, the reviewer studies were very interesting and provided a working basis for further studies. However, there is a pressing need to support more research and publications to improve QOL of Arab women with breast cancer in Arab countries where the breast cancer incidence rates have increased during recent years.

\section{Additional file}

Additional file 1: Excluded studies and reasons for exclusion. (DOC $55 \mathrm{~kb}$ )

\section{Abbreviations}

AIM: African Journals Online and African Index Medicus; ASR: age-djusted standardized incidence rates; BITS: Breast Impact of Treatment Scale; BSS: Body Satisfaction Scale; EORTC: European Organization for Research and Treatment of Cancer; FACT-B: Functional Assessment of Cancer TherapyBreast; LASA: Linear Analogue Self-Assessment; PRISMA: Preferred Reporting Items for Systematic Reviews and Meta-Analyses; QLQ-BR23: European Organization for Research and Treatment of Cancer breast cancer- specific quality of life questionnaire; QLQ-C30: European Organization for Research and Treatment of Cancer Core quality of life questionnaire; QOL: quality of life; UAE: United Arab Emirates; WHO: World Health Organisation.

\section{Competing interests}

The authors declare that they have no competing interests.

\section{Authors' contribution}

All the authors have made substantive intellectual contributions to the study. BHR made substantial contributions to conception and design, acquisition, analysis, and interpretation of data and wrote the manuscript. Abdelhalem M, $\mathrm{KE}$ provided comments regarding the data and analysis and revised the manuscript for important intellectual content. FO assisted with manuscript review and revision. Ali $\mathrm{M}$ has been involved in drafting the manuscript, revising it critically for important intellectual content. CN and RB critically reviewed the manuscript. All authors read and approved the final manuscript.

\section{Acknowledgements}

We thank "Fondation Lalla Salma Prevention and Treatment of Cancers". We thank Pr Raouf Alami, Pr Mohamed Badaoui Dr Zakia Cheikh and Dr Corine Verhoeven for rereading this manuscript.

\section{Author details}

${ }^{1}$ Laboratory of Genetic, Neuroendocrinology and Biotechnology, University Ibn Tofail, Faculty of Sciences, Kenitra, Morocco. ${ }^{2}$ Department of

Epidemiology and Public Health, Faculty of Medicine and pharmacy of Fez, Sidi Mohamed Ben Abdillah University, Sidi Mohamed Ben Abdillah, Morocco. ${ }^{3}$ Fondation Lalla Salma Prevention and Treatment of Cancers, Rabat, Morocco. ${ }^{4}$ Mental Health Research Group, Health Metrics Research Centre, Iranian Institute for Health Sciences Research, ACECR, Tehran, Iran.

Received: 31 August 2015 Accepted: 18 April 2016

Published online: 27 April 2016

\section{References}

1. Lehto US, Ojanen M, Kellokumpu-Lehtinen P. Predictors of quality of life in newly diagnosed melanoma and breast cancer patients. Ann Oncol. 2005;16:805-16.

2. Wilsoff F, Hjorth M. Health-related quality of life assessed before and during chemotherapy pre-dicts for survival in multiple myeloma. Br J Haematol. 1997;97:29-37.

3. Montazeri A, Gillis CR, McEwen J. Measuring quality of life in oncology: is it worthwhile? Part I. Meaning, purposes, and controversies. Eur J Cancer Care. 1996;5:159-67.

4. Montazeri A, Gillis CR, McEwen J. Measuring quality of life in oncology: is it worthwhile? Part II. Experiences from the treatment of cancer. Eur J Cancer Care. 1996:5:168-75. 
5. Montazeri A, Milroy R, Hole D, McEwen J, Gillis CR. How quality of life data contribute to our understanding of cancer patients'experiences? A study of patients with lung cancer. Qual Life Res. 2003;12:157-66.

6. Montazeri A, Milroy R, Hole D, McEwen J, Gillis CR. Quality of life in patients with lung cancer: as an important prognostic factor. Lung Cancer. 2001;31:233-40

7. Ferlay J, Soerjomataram I, et al. GLOBOCAN 2012 v1.0: Cancer Incidence and Mortality Worldwide: IARC CancerBase No. 11. International Agency for Research on Cancer. 2013. Available from: http://globocan.iarc.fr.

8. Ferlay J, Autier P, Boniol M, et al. Estimates of the cancer incidence and mortality in Europe in 2006. Ann Oncol. 2007;18:581-92.

9. Montazeri A, Vahdaninia M, Harirchi I, Ebrahimi M, Khaleghi F, Jarvandi S. Quality of life in patients with breast cancer before and after diagnosis: an eighteen months follow-up study. BMC Cancer. 2008;8:330.

10. Pandey M, Singh SP, Behere PB, Roy SK, Singh S, Shukla VK. Quality of life in patients with early and advanced carcinoma of the breast. Eur J Surg Oncol. 2000;26:20-4.

11. El Saghir NS, Khalil MK, Eid T, et al. Trends in epidemiology and management of breast cancer in developing Arab countries: a literature and registry analysis. Int J Surg. 2007:5:225-33.

12. Bates MS, Rankin-Hill L, Sanchez-Ayendez M. The effects of the culture context of health care on treatment of and response to chronic pain and illness. Soc Sci Med. 1997:45:1433-47.

13. Taleghani F, Parsa Z, Nasrabadi AN. Coping with breast cancer in newly diagnosed Iranian women. J Adv Nurs. 2006:54:265-72.

14. Scott NW, Fayers PM, Aaronson NK, Bottomley A, de Graeff A, Groenvold M, Koller M, Petersen MA, Sprangers MA, EORTC Quality of Life Group; Quality of Life Cross-Cultural Meta-Analysis Group: Collaborators The relationship between overall quality of life and its subdimensions was influenced by culture: analysis of an international database. J Clin Epidemiol. 2008;61:788-95.

15. PRISMA (Preferred Reporting Items for Systematic Reviews and MetaAnalyses) statement criteria. [http://www.prisma-statement.org].

16. Jassim GH, Whitford DL. Understanding the experiences and quality of life issues of Bahraini women with breast cancer. Soc Sci Med. 2014;107:189-95.

17. El Sharkawi FM, Sakr MF, Atta HY, Ghanem HM. Effect of different modalities of treatment on the quality of life of breast cancer patients in Egypt. La revue de santé de la méditeranée orientale, 1997;3(1):68-81.

18. Awad MA, Denic S, El Taji H. Validation of the european organization for research and treatment of cancer quality of life questionnaires for Arabic-speaking populations. Ann N Y Acad Sci. 2008;1138:146-54.

19. Alawadi SA, Ohaeri JU. Health - related quality of life of Kuwaiti women with breast cancer: a comparative study using the EORTC quality of life questionnaire. BMC Cancer. 2009;9:222.

20. Masmoudi A, Frikha M, Daoud J. Feasibility of quality of life assessment in routine clinical oncology practice: a Tunisian study. La Revue de Santé de la Méditerranée orientale. 2009;15(2):362-8.

21. Mostafa ESM, Sadek RR, El-Sherif MA, Saber RA, Mosalem FA. Assessment of quality of life for female breast cancer patients attending el-minia oncology center from June to December 2009. El-minia med bul. 2010;21(1):161-70.

22. Al-Naggar RH, Nagi NMS, Saleh Ali MM, Almuasli M. Quality of life among breast cancer patients in Yemen. Asian Pacific Journal of Cancer Prevention. 2011;12:2335-41

23. Huijer HA, Abboud S. Health-related quality of life among breast cancer patients in Lebanon. Eur J Oncol Nurs. 2012;16:491-7.

24. Denewer A, Farouk O, Kotb S, Setit A, Abd Elkhalek S, Shetiwy M. Quality of life among Egyptian women with breast cancer after sparing mastectomy and immediate autologous breast reconstruction: a comparative study. Breast Cancer Res Treat. 2012;133:537-44.

25. Ba-Khubaira S, Al-Kahiry W. Age related quality of life among selected breast cancer patients in Aden, Yemen. Pan Arab Journal of Oncology. 2012;5(1):14-7.

26. Jassim GH, Whitford DL. Quality of life of Bahraini women with breast cancer: a cross sectional study. BMC Cancer. 2013:212. doi:10.1186/14712407-13-212.

27. El Fakir S, Abda N, et al. The European organization for research and treatment of cancer quality of life questionnaire-BR 23 breast cancer-specific quality of life questionnaire: psychometric properties in a Moroccan sample of breast cancer patients. BMC Research Notes. 2014;7-53.

28. Abu-Helalah M, Al-Hanaqta M, Alshraideh H, Abdulbaqi N, Hijazeen J. Quality of life and psychological well-being of breast cancer survivors in Jordan. Asian Pac J Cancer Prev. 2014;15:5927-36.
29. Perry S, Kowalski T, Chang C. Quality of life assessment in women with breast cancer: benefits, acceptability and utilization. Health Qual Life Outcomes. 2007;5:24.

30. King MT, Fayers PM. Making quality-of-life results more meaningful for clinicians. Lancet. 2008;371(9614):709-10.

31. Osoba D, Rodrigues G, Myles J, Zee B, Pater J. Interpreting the significance of changes in health-related quality-of-life scores. J Clin Oncol. 1998;16:139-44.

32. Guyatt GH, Osoba D, Wu AW, Wyrwich KW, Norman GR, Clinical Significance Consensus Meeting Group. Methods to explain the clinical significance of health status measures. Mayo Clinic Proc. 2002;77:371-83.

33. Cocks K, King MT, Velikova G, Fayers PM, Brown JM. Quality, interpretation and presentation of european organisation for research and treatment of cancer quality of life questionnaire core 30 data in randomized controlled trials. Eur J Cancer. 2008:44:1793-8.

34. Hoyer M, Johansson B, Nordin K, Bergkvist L, Ahlgren J, Lidin-Lindqvist A, et al. Health-related quality of life among women with breast cancer-a population-based study. Acta Oncol. 2011

35. Lee TS, Kilbreath SL, Refshauge KM, Pendlebury SC, Beith JM, Lee MJ. Quality of life of women treated with radiotherapy for breast cancer. Support Care Cancer. 2008:16:399-405.

36. Stavrou D, Weissman O, Polyniki A, Papageorgiou N, Haik J, Farber N, Winkler E. Quality of life after breast cancer surgery with or without reconstruction. J Plast Surg. 2009;9:161-8.

37. Hebert R, Zdaniuk B, Schulz R, Scheier M. Positive and negative religious coping and well-being in women with breast cancer. J Palliat Med. 2009;12:537-45

38. Safaee A, Moghimi-Dehkordi B, Zeighami B, Tabatabaee HR, Pourhoseingholi MA. Predictors of quality of life in breast cancer patients under chemotherapy. Indian J Cancer. 2008

39. Janz NK, Mujahid M, et al. Population-based study of the relationship of treatment and sociodemographics on quality of life for early stage breast cancer. Qual Life Res. 2005;14:1467-79.

40. Cui $Y$, Shu $X O$, et al. The long-term impact of medical and sociodemographic factors on the quality of life of breast cancer survivors among Chinese women. Breast Cancer Res Treat. 2004;87:135-47.

41. Engel J, Kerr J, et al. Predictors of quality of life of breast cancer patients. Acta Oncologica. 2003:42:710-18.

42. Musarezaie A, Ghasemi TM, Esfahani HN. Investigation the quality of life and its relation with clinical and demographic characteristics in women with breast cancer under chemotherapy. Int J Prev Med. 2012;3:853-9.

43. Sprague BL, Trentham-Dietz A, Gangnon RE, Ramchandani R, Hampton JM, et al. Socioeconomic status and survival after an invasive breast cancer diagnosis. Cancer. 2011;117:1542-51.

44. Salonen P, Tarkka MT, Kellokumpu-Lehtinen PL, Astedt-Kurki P, Luukkaala T, et al. Telephone intervention and quality of life in patients with breast cancer. Cancer Nurs. 2009:32:177-90.

45. Peuckmann V, Ekholm O, Rasmussen NK, et al. Health-related quality of life in long-term breast cancer survivors: nationwide survey in Denmark. Breast Cancer Res Treat. 2007;104:39-46.

46. Esbensen BA, Osterlind K, Roer O, Hallberg IR. Quality of life of elderly persons with newly diagnosed cancer. Eur J Cancer Care. 2004;13:443-53.

47. Pandey M, Thomas BC, Ramdas K, Ratheesan K. Early effect of surgery on quality of life in women with operable breast cancer. Jpn J Clin Oncol. 2006:36:468-72.

48. Arndt V, Merx H, Tturmera S, Stegmaierc C, Zieglerc H, Brennera $H$. Age-specific detriments to quality of life among breast cancer patients one year after diagnosis. Eur J Cancer. 2004;5:673-80.

49. Morrow PK, Broxson AC, Munsell MF, Basen-Enquist K, Rosenblum CK, et al. Effect of age and race on quality of life in young breast cancer survivors. Clin Breast Cancer. 2014;14:e21-31.

50. Benton MJ, Schlairet MC, Gibson DR. Change in quality of life among breast cancer survivors after resistance training: is there an effect of age? J Aging Phys Act. 2014;22:178-85.

51. Ogce F, Ozkan S, Baltalarli B. Psychosocial stressors, social support and socio demographic variables as determinants of quality of life of Turkish breast cancer patients. Asian Pac J Cancer Prev. 2007;8:77-82.

52. Huijer HA, Abboud S. Predictors of Quality Of Life in a Sample of Lebanese Patients with Cancer. Europe's J Psychol. 2013;9:8-18.

53. Nejiari C, El Fakir S, et al. Translation and validation of European organization for research and treatment of cancer quality of life 
questionnaire -C30 into Moroccan version for cancer patients in Morocco. BMC Research Notes. 2014;7:228.

54. Mnif L, Masmoudi J, Charfi N, Damak R, Guermazi M, Jaoua A. Quality of life of Tunisian women after the treatment of breast cancer. Abstracts of the 19th European Congress of Psychiatry. 2011;26(1):987.

55. Butow PN, Aldridge $L$, et al. Inferior health-related quality of life and psychological well-being in immigrant cancer survivors: a population-based study. Eur J Cancer. 2013;49:1948-56.

56. Abu Obead K, Batiha A, Al-Jauissy MS, Alhalaiqa F, AlBashtawy M. Impact of radiotherapy treatment on Jordanian cancer patients' quality of life and fatigue. International Journal of Advanced Nursing Studies. 2014;3(1):6-12.

57. Lazenby M, Khatib J. Associations among patient characteristics, healthrelated quality of life, and spiritual well-being among arab Muslim cancer patients. Journal of palliative medicine. 2012;15:2.

58. Hoopman R, Muller MJ, Terwee CB, Aaronson NK. Translation and validation of the EORTC QLQ-C30 for use among Turkish and Moroccan ethnic minority cancer patients in the Netherlands. Eur J Cancer. 2006:4 2:1 83 9-4 7 .

Submit your next manuscript to BioMed Central and we will help you at every step:

- We accept pre-submission inquiries

- Our selector tool helps you to find the most relevant journal

- We provide round the clock customer support

- Convenient online submission

- Thorough peer review

- Inclusion in PubMed and all major indexing services

- Maximum visibility for your research

Submit your manuscript at www.biomedcentral.com/submit
Biomed Central 